\title{
La pose autobiográfica. Ensayos sobre narrativa chilena
}

Lorena Amaro Castro (2018). Santiago de Chile, Ediciones Universidad Alberto Hurtado, 400 pp.

\section{* María José Punte \\ Universidad Católica Argentina UNTREF}

El libro de Lorena Amaro funciona como una caja de resonancia de las numerosas discusiones en torno a las así llamadas "escrituras del yo", en una instancia en la que la crítica literaria se confronta de manera cada vez más asidua con estas formas de narrar. En diálogo amoroso con lo que Leonor Arfuch había ya definido como el "espacio biográfico", el volumen despliega una gran variedad de escrituras biográficas en la literatura chilena desde el siglo XIX hasta el presente. De esa manera, ofrece otra entrada a esta literatura que sorprende por la cantidad de posibilidades no exploradas aún por la crítica, para volver a pensar textos a los que ya se había encajonado o relegado a los estantes pertinentes del canon literario. La figura que recupera y que establece otro diálogo transamericano es la de la "pose", gesto que no solo homenajea a Sylvia Molloy, sino que la ratifica en su papel de precursora. Este tejido de voces críticas, con toda la carga de una conciencia que se reconoce feminista, se instala en territorios en los que todavía hace falta explorar las presencias de autoras, de sus obras y de sus actuaciones en el campo cultural. Sin embargo, la mirada feminista no se aquieta en esta labor de recuperación, sino que propone volver a releer el canon masculino para observar qué nos dice ahora que ya nos ve.

El volumen reúne textos que habían sido publicados con anterioridad en diversas revistas académicas y atraviesan un recorrido que Amaro viene trazando desde hace más de una década. Pero hay un reordenamiento y una nueva articulación de estos ensayos críticos que operan en este armado de la literatura chilena ofreciendo de esa manera una lectura comprensiva y actualizada, en la que el detalle olvidado o el dato poco atendido adquieren nuevas dimensiones. Parafrasea una dinámica como la del rompecabezas: hay que esperar a colocar la última pieza para poder ver la figura. Más allá de la copiosa información que presenta el texto, y que lo convierte en una herramienta fundamental para un abordaje de la literatura chilena a partir de perspectivas actuales, la pregunta central que desafía las representaciones es la que abre el texto: ¿quién dice yo? Esta escueta interrogación que parece estar hablando de las diversas formas de construir una persona narrativa (en sus formatos tan variados que van desde la autobiografía hasta el diario, pasando por la autoficción), se revela en todo su doble sentido para apuntar a los modos androcéntricos de construir el lenguaje, los géneros textuales, así como las lecturas hechas sobre esa biblioteca.

El volumen se organiza en tres partes, división que exige un esfuerzo interpretativo. En la primera de ellas, “Autoría y herencias", el derrotero parte de una mirada general y omnicomprensiva sobre la producción del relato autobiográfico en Chile, que se sustenta en el trabajo dedicado por Amaro a unos setenta textos. Una de las conclusiones que surge es la de que, en Chile, estos relatos que son tan esquivos como fronterizos, van produciendo "el lento tejido de nuestra diferencia" (43). En el primero de los ensayos, "Que les perdonen la vida", centrado en la autobiografía y memorias de la primera mitad del siglo XX, la autora toma como punto de partida la constatación de la índole memorialística de esta escritura, pero que en Chile se encuentra más vinculada con modelos identitarios colectivos que con la idea de "relato de persona real" enfatizada por Philippe Lejeune. La autora pone el acento en el "buen tono" autojustificatorio como uno de sus rasgos llamativos, pero también en las formas híbridas adoptadas por el género que la llevan a referirse a su carácter de "excedente".

El segundo capítulo, "Vicarias, intrusas, rebeldes" se referirá a cuatro autoras, a las que volverá de manera 
intermitente en varios momentos del volumen: Inés Echevarría, María Flora Yáñez, Rita Salas y Delia Rojas. En el contexto de este período de comienzos de siglo caracterizado por un desplazamiento en el campo literario desde las elites políticas y económicas hacia un nuevo orden que tiende a separar lo político de lo literario, las autoras mujeres expresan un "fuerte potencial contrahegemónico" (65), a pesar de provenir ellas mismas de esos grupos sociales de elite. La literatura autobiográfica femenina da cuenta de procesos constructivos, más que de productos acabados, nos dice Amaro, por lo que sus textos constituyen "traducciones" de las formas en que se van tramando las subjetividades.

Los siguientes dos capítulos van a estar dedicados de modo específico a las mencionadas Martina Barros y su texto Recuerdos de mi vida (1945), texto largamente soslayado en Chile según nos recuerda Amaro, y a María Flora Yáñez, autora de Visiones de infancia (1947) e Historia de mi vida (1980). El pasaje que la autora hace desde el texto dedicado a Alone, el alias de Hernán Díaz Arrieta (1891-1984), hasta Pablo Neruda con su lectura de Confieso que he vivido, habla a las claras de la relectura del canon que tendió a ser masculinizante, propuesta visibilizada por Amaro desde su pertinente sesgo de género. Ambos autores despliegan sus propias "operaciones de impostación”, pero de signo lo suficientemente opuesto.

En la segunda sección, "Postales de infancia", vuelve a resonar el carácter público de la escritura autobiográfica en Chile, así como la tardía entrada del relato de infancia, rasgos que Molloy había hecho extensivo a América Latina. Amaro se pregunta en "Las caras de la infancia en Chile" si en este caso particular no jugaría también su rol la vinculación de lo social con lo simbólico, es decir, la lenta incorporación de los derechos del niño en el entramado nacional. Por otro lado, haciendo una torsión por la impronta queer de la infancia en la cultura y sus posibilidades de extrañamiento, indaga en los lazos de esta con una estética de la memoria, a la vez creadora y distorsionadora, lo que ella ve como una marca de la literatura contemporánea. A la extensa nómina de lo que hoy se denomina la "literatura de los hijos", esta sección suma trabajos sobre José Santos González Vera (1897-1970) y Manuel Rojas (1896-1973), sobre las obras de Luis Oyarzún (1920-1972) y la de Mauricio Wacquez (1939-200o). Estos artículos dedicados a autores que se remontan hacia atrás en el tiempo, van siendo intercalados con otros en los que la autora explora las metáforas que la infancia ofrece como modelo de interpretación para la historia y la política chilenas. En "Volatines y pájaros" se trata de este objeto propio de la niñez, el volatín, utilizado en la literatura para referirse tanto a los discursos del fracaso como a los de la utopía. En "Lecturas huachas" retoma esta conocida figura de la literatura chilena vinculada con la orfandad, que para la generación crecida bajo el pinochetismo tiene que ver con una condición cultural resultante del "apagón cultural”. En "Formas de salir de casa, o cómo escapar del ogro", lee las producciones más recientes desde el concepto de "relatos de filiación" de Dominique Viart. La imagen que usa en este apartado para las formas representacionales de las "postales" hace referencia a un tipo de imágenes que son inútiles y decorativas, caracterizadas a su vez por la velocidad.

La tercera parte incluye cinco textos bajo el somero título "Autobiografías, autoficciones". En "La pose autobiográfica" se dedica de modo específico a esta noción que remite tanto a Molloy como a Estrella de Diego y su libro No soy yo (2011). Le sirve para armar una serie desde una temporalidad retroactiva y que va desde Lina Meruane hasta Augusto D'Halmar y Cristián Huneeus, a quien le dedicará a continuación el siguiente capítulo. En "La madre de la revolución" se ocupa de las obras de la escritora y documentalista Carmen Castillo (1945). En el capítulo "Autobiografía y crítica literaria en Chile: las formas del complot", retorna la figura desprejuiciada de Alone, pero centrándose ahora en su Historia personal de la literatura chilena (1954), a partir de la cual la autora propone la idea de la "crítica como autobiografía". Esta conjunción entre autobiografía y crítica que fue siguiendo a lo largo de todo el volumen, adquiere la forma del complot, concepto que ella retoma de Ricardo Piglia para pensar el género en Chile. Se trata de una tradición que va por abajo y que le permite a Amaro seguir ese derrotero que va desde Alone hasta Roberto Bolaño, y que llega hasta Álvaro Bisama y Alejandro Zambra. Por último, el texto "Una autobiografía de terror", referido a un cuento de Bolaño, le sirve para hacer explícita esta idea de que hay que leer los textos desde el detalle, es decir, desde el nuevo punto de vista que instala el detalle. La idea de "terror" que se cuela en este último capítulo con la aparición de los zombis mediante el cuento de Bolaño, dialoga con el texto anterior de las historias efectivamente terroríficas de las que deja testimonio en sus obras Carmen Castillo.

Esta historia atípica de los textos autobiográficos chilenos se muestra, entonces, como acéfala: no hay una jerarquización que conduzca a un corpus orgánico. Sostiene la tesis de que leer es leerse. Las y los escritores chilenos que se dedicaron a las variadas formas de escritura biográfica dan cuenta 
de una diversidad que desafía las taxonomías. La compilación que hace Lorena Amaron de esas formas revela dicha variedad polícroma en un viaje lleno de vértigo por casi dos siglos de escritura. A pesar de las sombras que traman esa historia, despiertan el apetito por lanzarse a devorar tantos de esos textos, creando una nueva categoría para la lectura que se hace comprensible, justamente, a partir de la escritura de Roberto Bolaño: la posibilidad de que exista algo así como lectores zombis. 
